Іванов О В.

(0000-0003-0878-7939);

Кузнєцов Д. О.

(0000-0003-2749-7013);

Григорак С. В.

(0000-0002-0186-2492);

Лук'янчіков I. М.

(0000-0001-6800-2510);

Ошкодер С. В.

(0000-0003-1261-1055)

Командно-штабний інститут застосування військ (сил) Національного університету оборони України імені Івана Черняховського, Київ

\title{
Показники оцінювання інформативної доступності джерел радіовипромінювання противника для добування розвідувальних даних засобами радіоелектронної розвідки
}

Резюме. У статті наведено вибір показників оцінювання інформативної доступності джерел радіовипромінювання противника засобами радіоелектронної розвідки для використання в засобах автоматизації різних ланок управління радіоелектронної розвідки. Наведено узагальнений показник інформативної доступності на основі використання сучасних розвідувально-інформаційних моделей.

Ключові слова: радіоелектронна розвідка, інформативна доступність, об’єкти розвідки, джерела радіовипромінювань.

Постановка проблеми. у радіоелектронній розвідці (РЕР) під інформативною (розвідувальною) доступністю (ІД) джерел радіовипромінювання системи управління та зв'язку розуміється сукупність притаманних розвідувальній системі ознак, які дають змогу розкрити системи управління та зв'язку противника із заданою вірогідністю за заданий час [1-3].

Інформативна доступність тією чи іншою мірою оцінюється для вирішення таких завдань:

ведення пошуку джерел і об'єктів РЕР;

розподілу об'єктів і джерел РЕР під час планування РЕР;

розподілу сил і засобів за завданнями, об'єктами та джерелами;

оцінювання

ефективності

розроблюваних засобів і комплексів.

На практиці оцінювання ІД повною мірою не здійснюється $[4,5]$.

На сьогодні відсутній методичний апарат оцінювання можливостей сил і засобів радіоелектронної розвідки за інформативною (розвідувальною) доступністю джерел радіовипромінювання, для використання в засобах автоматизації різних ланок управління PEP $[4,6]$

Аналіз останніх досліджень i публікацій. Питання формалізації, а тим більше автоматизації основних процесів оцінювання ІД для різних умов РЕО і окремих етапів ведення бойових дій не розв'язані.
Причинами основних недоліків у практиці оцінювання ІД є недоліки науковометодичного апарату.

Актуальність теми дослідження обумовлена [7-9]:

відсутністю загального підходу вибору показників оцінювання можливостей сил i засобів РЕР за оцінкою інформаційної (розвідувальної) доступності джерел РЕР, придатної для використання в засобах автоматизації різних ланок управління розвідки, що зв'язує окремі показники ІД в узагальнений на основі використання розвідувально-інформаційних моделей (PIM); низькою критичністю до розв'язуваної задачі використовуваних часткових показників ІД у вигляді якісних оцінок, відсутність кількісного опису більшості з них; низькими показниками адекватності застосовуються моделей, особливо на перспективних системах зв'язку, для угруповань “модульних сил”, їх систем управління на базі комплексних АCУ та комунікаційних систем загального користування 3 низькою структурної доступністю, які використовують мережі із самоорганізацією і супутникові системи зв'язку (програма WIN-T) [10].

Без розв'язання зазначених проблем якість виконання завдання оцінювання можливостей сил $\mathrm{i}$ засобів PEP 3 інформативної (розвідувальної) доступності джерел РЕР в інтересах розподілу сил і засобів 
під час планування РЕР, виконання завдань за призначенням, неухильно знижуватиметься.

Метою статті $є$ вибір показників оцінювання інформативної (розвідувальної) доступності джерел радіовипромінювання противника для добування розвідувальних даних засобами радіоелектронної розвідки.

Виклад основного матеріалу. Оцінювання можливостей сил і засобів РЕР 3 інформативної (розвідувальної) доступності джерел РЕР є елементом загальної методики розподілу сил і засобів розвідки і являє собою сукупність статистичних і логічних методів розрахунку, які застосовуються в певній логічній послідовності для формування адекватних складових - потенційної, технічної та реальної ІД джерел РЕР.

Показники дають змогу оцінювати джерела РЕР з погляду доцільності включення в план розподілу сил і засобів для різних умов обстановки, ефективно управляти силами i засобами РЕР в інтересах вирішення завдань і оцінювати ступінь цієї ефективності. Вони описують класи станів діяльності, їх взаємозв'язок 3 об'єктами і джерелами, характеристики останніх 3 інформаційних груп, розподілу за глибиною i виявом в об'єктах РЕР, а також оптимальні бойові порядки підрозділу, військової частини РЕР для різних умов обстановки [10].

Вихідними даними для оцінювання ІД є: розвідувально-інформаційні моделі станів угруповання противника (гіпотетичні, еталонні та робочі) [4];

бойовий і чисельний склад угруповання противника;

довідкові дані з бойового застосування

3С, СУ і РТ3;

склад сил і засоби РЕР і їх оперативнотехнічні характеристики.

Під час вирішення завдань оцінювання можливостей сил і засобів РЕР за ІД джерел РЕР введені такі обмеження і допущення:

ознакова доступність джерел РЕР визначається 3 погляду вирішення завдань розпізнавання оперативно-тактичного призначення (ОТП) джерел, розкриття через них об'єктів;

оцінювання можливостей за ІД проводиться насамперед в інтересах розподілу сил і засобів і $є$ найважливішим компонентом під час розрахунку важливості (інформативності) джерела розвідки, яка

$$
P_{\text {потд }}(i)=1-\left\lfloor 1-P_{\text {семд }}(i)\right\rfloor \cdot\left[1-P_{\text {ознд }}(i)\right] \cdot\left[1-P_{\text {стр }}(i)\right\rfloor . \text { (2) }
$$

Імовірність технічної доступності $\left(P_{\text {mехд }}\right)$ джерел РЕР розраховуватиметься як визначається ймовірністю ІД джерела $P_{\text {д }}$, важливістю об’єктів, які входять до складу джерела, кількістю об'єктів у мережі;

ресурс розподіляється для всіх типів постів як наявних комплексів, так i перспективного комплексу [2], пости керування і обробки враховуються під час розрахунку розвідувальної (ознакової) доступності [6];

модель організації пошуку i спостереження - послідовна, пошук ведеться за частотою, простором і ознаками джерел.

Для оцінювання інформативної доступності джерел РЕР введено узагальнені та часткові показники, зважаючи на міркування, які наведені нижче.

Узагальнений показник ІД визначимо 3 урахуванням таких складових показників оцінки у вигляді реальної розвідувальної доступності на основі статистичної моделі [6]:

імовірність потенційної доступності $P_{\text {nотд }}$, яка складається 3 часткових показників ІД імовірностей семантичної доступності $P_{\text {семд }}$, ознакової $P_{\text {ознд }}$ i структурної $P_{\text {стрд }}$ доступності;

імовірність технічної доступності $P_{\text {mexд }}$, яка складається 3 часткових показників ІД імовірностей електромагнітної $P_{\text {eмд }}$, просторової $P_{\text {простд }}$, апаратурної $P_{\text {anард }}$ доступності.

Ймовірність характеризує в основному власні можливості системи РЕР за виявленням комунікаційних процесів різних рівнів.

Тоді узагальнений показник можливостей сил і засобів PЕР за ІД $i$-го джерела матиме вигляд

$$
P_{\text {інфд }}(i)=P_{\text {mex }}(i) P_{\text {nотд }}(i),
$$

де $i$ - порядковий номер джерела РЕР;

$P_{\text {mех }}(i)$ - імовірність технічної доступності i-го джерела РЕР;

$$
P_{\text {потд }}(i)-\text { імовірність потенційної }
$$

інформативної доступності $i$-го джерела РЕР.

Імовірність потенційної доступності $P_{\text {nотд }}(i) \quad i$-го джерела РЕР визначатиметься реалізацією хоча б однієї події можливості складових іiі елементів і обчислюється за формулою

перетин подій реалізації складових іï елементів: 


$$
P_{\text {mех } \partial_{i}}=P_{\text {емд }} P_{\text {просторо }} P_{\text {anapd }}
$$

Для прийняття рішення про включення джерела РЕР в план розподілу сил і засобів за показником інформативної доступності (без урахування повноти охоплення об'єктів розвідки) доцільно вибрати такі критерії:

при $P_{\text {інфд }}<0,2$ (низька) - джерело недоцільно планувати для включення в план розподілу сил і засобів для ведення РЕР;

при $P_{\text {інфо }}=0,2-0,5 \quad$ (середня) можливо планування джерела для ведення PEP;

при $P_{\text {інфо }}>0,5$ (висока) - джерело доцільно планувати для ведення розвідки.

Розглянемо окремі показники інформативної доступності, синтезуючи їх в імовірнісному вигляді.

$$
P_{\text {семд }}(i)=K_{6}(i) P_{\text {семдв }}(i)+K_{k}(i) P_{\text {семдк }}(i)+K_{u}(i) P_{\text {семди }}(i)+K_{\phi}(i) P_{\text {семд } \phi}(i),
$$

де $K_{6}(i), K_{\kappa}(i), K_{u}(i), K_{\phi}(i)$ - коефіцієнти, що враховують частку відкритих, кодованих, шифрованих, формалізованих повідомлень у роботі $i$-го джерела, які розраховується як відношення числа відкритих, кодованих, шифрованих, формалізованих повідомлень до загального відповідно;

$$
P_{\text {семдв }}(i), P_{\text {семдк }}(i), P_{\text {семдм }}(i), P_{\text {сем } \phi}(i) \text { - ймовірно }
$$

сті семантичної доступності відкритих, кодованих, шифрованих, формалізованих повідомлень, які виражається як відношення доступних i недоступних повідомлень виявлення семантичних розвідувальних ознак для розпізнавання об'єктів розвідки і їх станів відповідно.

Ознакова доступність визначається стійкістю виявлення розвідувальних ознак системи зв'язку та радіотехнічного

$$
P_{\text {ознд }}(i)=1-\left[1-P_{\text {озн } 1}(i)\right. \text {. }
$$

де $P_{\text {озн1 }}(i)$ - імовірність оперативно-тактичного призначення $i$-го джерела об'єкта розвідки;

$P_{\text {озн } 2}(i)$ - імовірність оперативно-тактичної приналежності об'єкта розвідки через джерела РЕР;

$P_{\text {озн }}(i)$ - імовірність виявлення стану діяльності об’єкта розвідки через джерела РЕР.

Розрахунок імовірності розпізнавання $i$-го джерела проводиться відповідно до статистичної теорії розпізнавання (для джерел - схема Байєса, для об'єктів -
Семантична доступність системи управління визначається ступенем використання в ній апаратури індивідуального та групового лінійного шифрування, застосуванням структурного шифрування, стійкістю використовуваних при радіообміні методів прихованого управління військами, виявленням семантичних розвідувальних ознак для розпізнавання об'єктів і їх стану.

Для розрахунку можливостей сил i засобів РЕР за семантичною доступністю джерела логічно розрахувати частку відкритих, кодованих, шифрованих i формалізованих повідомлень у його роботі та 3 урахуванням доступності кожного типу повідомлень визначити сумарну їх імовірність як міру узагальненої доступності.

У цьому випадку ймовірність семантичної доступності $i$-го джерела розраховуватиметься за формулою

забезпечення, а також витратами ресурсу сил $\mathrm{i}$ засобів на виявлення або підтвердження їх.

Унаслідок проведеного аналізу встановлено, що доцільніше оцінювати ознакову доступність за стійкістю виявлення (інформативності) структурно-статистичних (логічних) розвідувальних ознак розпізнавання:

оперативно-тактичного призначення джерела РЕР;

оперативно-тактичної приналежності (ОТП) об'єкта розвідки через джерела РЕР; станів діяльності об'єкта розвідки через джерела РЕР.

Очевидно, що можливості сил і засобів РЕР за ознаковою доступністю джерел виражатимуться через імовірності ознакової доступності джерел $P_{\text {ознд }}$, яка в цьому випадку розраховуватиметься за формулою $\left.P_{\text {озн } 2}(i)\right] \cdot\left[1-P_{\text {озн } 3}(i)\right]$, (4)

розпізнавання через головні та підлеглі станції радіомережі, де виявляється цей об'єкт, для станів діяльності - на основі логічного методу шляхом аналізу i прийняття рішення про виявлення розвідувальних ознак через джерела (0 або 1) [5].

Структурна доступність системи зв'язку визначається ступенем відповідності структури системи зв'язку та радіотехнічного забезпечення в структурі системи управління військами і зброєю.

Можливості сил і засобів РЕР щодо структурної доступності логічно виражати через імовірність структурної доступності, на 
величину якої впливатимуть ступінь відповідності структури (просторової i управлінської) системи зв'язку структурі системи управління, точність визначення місцезнаходження джерел радіовипромінювання, що дає змогу розділити на місцевості кореспондентів мережі, а також виявити зміну місця розташування джерел (об'єктів) у разі зміни стану угруповання.

3 огляду на значні затрати часу i складності проведення розрахунків точності визначення місцезнаходження для кожного кореспондента мережі, визначення кількісної оцінки ступеня відповідності системи зв'язку системі управління, доцільно проводити аналіз імовірності структурної доступності на підставі середніх оцінок за типами систем зв'язку i градацій віддалення від лінії зіткнення військ:

$$
P_{\text {стр }}=0,5-0,75 \quad \text { для } \quad \text { командного }
$$

зв'язку,

$$
P_{\text {стр }}=0,1-0,3 \text { для систем зв'язку }
$$

загального користування.

Електромагнітна доступність джерел розвідки кількісно оцінюється максимальною відстанню між пунктами (районами) розташування засобів PEP i джерелами радіовипромінювання, які розвідуються, при якій забезпечується виявлення джерел.

Зміст традиційного показника докладно викладено в [10].

Під час оцінювання можливостей сил $\mathrm{i}$ засобів РЕР за електромагнітною доступністю джерел РЕР, які складаються 3 декількох джерел радіовипромінювання, виникають різні варіанти розрахунків: по головній станції мережі, площі мережі, найбільш віддаленого кореспонденту мережі.

Показник обліку розміщення об'єктів (джерел радіовипромінювання) під час

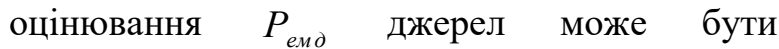
синтезований у такому вигляді:

за умови розташування об'єктів (джерел радіовипромінювання), які належать $i$-му джерелу, на всю глибину оперативної побудови, тобто в усіх зонах, приймаємо $P_{\text {емд }}=0,7$

за умови розташування в декількох зонах - $P_{e \text { eм }}=0,8$, тільки в одній зоні (в 1-му ешелоні, у 2-му або в резерві) - $P_{e м \partial}=1$.

Логічно вести розрахунок для максимальної електромагнітної доступності, а ймовірність просторової доступності визначати як відношення часу перебування $i$ го джерела радіовипромінювання в зоні максимальної електромагнітної доступності для відповідного місця установки засобів РЕР до циклу ведення розвідки:

$$
P_{\text {nрост }}(i)={ }^{t}(i) / T_{u},
$$

де $t_{p}(i)$ - загальний час знаходження джерела

в зоні максимальної електромагнітної доступності;

$T_{4}$ - загальний час циклу розвідки.

$$
\text { Апаратурна доступність } P_{\text {aпар }}
$$

визначається ступенем витрат сил і засобів РЕР на виявлення, пеленгування i перехоплення сигналів випромінювачів, які входять у розвідувальну систему зв'язку (радіотехнічного забезпечення).

Логічно розраховувати можливості по апаратурній доступності за найважливішими iї характеристиками, вираженими в імовірнісному вигляді:

за частотою $P_{a n f}$;

за видом сигналу $P_{\text {anсиг }}$;

за виглядом використовуваних передач $P_{\text {annep }}$.

Отже, ймовірність апаратурної доступності, 3 огляду на проведений аналіз, розраховуватиметься як перетин усіх трьох характеристик (подій):

$$
P_{\text {anapd }}=P_{\text {anf }} \cdot P_{\text {ancuzh }} \cdot P_{\text {annep }} .
$$

До того ж імовірність апаратурної доступності $i$-го джерела за частотою 3 урахуванням досить тривалого циклу ведення розвідки визначатиметься:

$$
P_{\text {aдf }}(i)=\Delta F_{\text {розв }} / \Delta F(i),
$$

де $\Delta F_{\text {розя }}$ - смуга частот джерела, у якій можливе приймання сигналу засобами розвідки;

$\Delta F(i)$ - діапазон частот, у якому можливе функціонування $i$-го джерела.

Імовірність апаратурної доступності за видом сигналу $P_{\text {anсизи }}$ необхідно розглядати як відношення кількості видів сигналів, які може використовувати $i$-те джерело та доступних для засобів РЕР (за демодуляцією, реєстрацією тощо) $K_{\text {розвсиги }}(i)$, до загальної кількості видів сигналу, на яких може функціонувати $i$-те джерело $K_{\text {джер сиги }}(i)$.

$$
P_{\text {апсигн }}(i)=K_{\text {розв сигн }}(i) / K_{\text {джсе сигн }}(i) \text {. }
$$

Імовірність апаратурної доступності за виглядом використовуваних передач сигналу $P_{\text {an пер }}$ може бути розрахована як відношення кількості видів передач, на яких функціонує 
джерело та сили і засоби розвідки, які здатні здійснювати їх перехоплення $K_{\text {розв пер }}(i)$, до загальної кількості видів передач, на яких функціонує це джерело $K_{\text {джер пер }}(i)$ :

$$
P_{\text {ап пер }}(i)=K_{\text {розв пер }}(i) / K_{\text {джер пер }}(i) \text {. }
$$

Отже, у загальному вигляді ймовірність апаратурної доступності $i$-го джерела розраховуватиметься як

$$
P_{\text {інфд }}=P_{\text {емд }} \cdot\left(t_{p} / T_{u}\right) \cdot\left(P_{\text {anf }} P_{\text {anсигн }} P_{\text {aпnер }}\right)\left\{1-\left[1-\sum_{j} K_{j} P_{j}\right]\left[1-\left(1-P_{\text {озн1 }} P_{\text {озн } 2}\right) \times\left(1-P_{\text {ознз }}\right)\right]\left[\left(1-P_{\text {стрд }}\right)\right]\right\} .
$$

де $K_{j}$ - коефіцієнти, що враховують частку відкритих, кодованих, шифрованих, формалізованих повідомлень, $j=\overline{1,4}$;

$P_{j}$ - імовірності семантичної доступності відкритих, кодованих, шифрованих, формалізованих повідомлень $j=\overline{1,4}$.

Висновок. Проведений у статті вибір показників оцінювання інформативної (розвідувальної) доступності джерел радіовипромінювання противника для добування розвідувальних даних засобами радіоелектронної розвідки дає змогу: оцінювати джерела PEP 3 погляду доцільності включення в план розподілу сил $і$ засобів за завданнями, об'єктами і джерелами, для різних умов обстановки;

раціонально управляти силами i засобами добування i обробки в інтересах вирішення завдань РЕР.

Цей підхід може бути застосований на командних пунктах угрупованнях військ, військових частин і підрозділів РЕР і дасть змогу раціонально розподілити сили і засоби за завданнями, об'єктами і джерелами.

Напрямом подальших досліджень слід вважати розроблення науково-методичного апарату підвищення ефективності ведення РЕР через проведення оцінювання ефективності наявних і перспективних засобів і комплексів РЕР і РЕБ.

\section{СПИСОК ВИКОРИСТАНОЇ ЛІТЕРАТУРИ}

1. Військовий стандарт 01.101.103. Воєнна розвідка. Радіоелектронна розвідка. Терміни та визначення. Київ : МО України, 2008. 22 с.

2. Варламов I. Д., Устименко О. В., Гаценко С. С. Шляхи удосконалення ведення радіоелектронного моніторингу засобів повітряного нападу. Новітні технології - для захисту повітряного простору : збірник матеріалів X наук. конф. Харківського національного університету Повітряних Сил імені Івана Кожедуба (м. Харків, 10-11 квіт. 2014 р.). Харків, 2014. С. 232-233.

$$
P_{\text {anapd }}(i)=P_{\text {anf }}(i) \cdot P_{\text {anсигн }}(i) \cdot P_{\text {annep }}(i) \text {. }
$$

Таким чином, формулу

(1) для розрахунку ймовірності інформаційної доступності джерела РЕP у розгорнутому вигляді з урахуванням (2) - (6) можна подати у вигляді:

3. Гончаров И. Ю. Теоретические основы радио- и радиотехнической разведки. Ленинград : ВАС, $1989.374 \mathrm{c}$

4. Смірнов Ю. О. Основи радіоелектронної розвідки. Частина 1. Розвідувально-інформаційний процес, основні моделі системи РЕР ефективність і напрями iii подальшого розвитку. Київ : НДІ ГУР МО України, 2009. 155 с.

5. Варламов I. Д., Гаценко С. С. Аналіз проблем інформаційного забезпечення органів військового управління при плануванні оборонної операції за досвідом проведення Антитерористичної операції на сході України. Основні напрямки застосування космічних систем та геоінформачійного забезпечення в інтересах національної безпеки $i$ оборони : матеріали наук.-практ. Семінару. Київ: НУОУ, 2015. C. 35-41.

6. Калашніков С. М., Гаценко С. С., Шишацький А. В. Аналіз характеру сучасних воєнних конфліктів. Challenges of hybrid war: information dimension : International scientific and practical conference (Vilnius, August 16-17, 2019). Vilnius, 2019. pp. 24 27.

7. Гаценко С. С., Бігун Н. С. Проблеми теорії та практики інформаційного протиборства в умовах ведення гібридних війн. Матеріали наук.-практ. конф. (м. Житомир, 24-25 жовтня 2019 р.) / відпов. за випуск Ставісюк Р. Л. Житомир, 2019. С. $155-$ 159.

8. I. Alieinykov, K. Thamer, Y. Zhuravskyi, O. Sova, N. Smirnova, R. Zhyvotovskyi, S. Hatsenko, S. Petruk, R. Pikul, A. Shyshatskyi. Development of a method of fuzzy evaluation of information and analytical support of strategic management. Eastern-European Journal of Enterprise Technologies. Vol. 6. № 2 (102). 2019. pp. 16-27. DOI: https://doi.org/ 10.15587/17294061.2019.184394.

9. Щерба А. А. Еволюція розвідувально-вогневої технології на основі мережецентричних принципів управління. Вісник Хмельницького національного університету. Хмелницький, 2014. № 4. С. 109-112. 10. Смирнов Ю. А. Радиотехническая разведка. Москва : Воениздат, 2001. 456 с. 


\section{Indicators for assessing the informative accessibility of enemy radio emission sources for obtaining intelligence by electronic intelligence}

\section{Annotation}

Radio-electronic intelligence (REI) means the information (intelligence) availability (IA) of radio sources of the control and communication system means a set of features inherent in the intelligence system, which allow to reveal the control and communication systems of the enemy with a given probability at a given time.

Informative accessibility is evaluated for the following tasks:

search for sources and objects of REI;

distribution of REI objects and sources during planning REI;

division of forces and means by tasks, objects and sources;

evaluation of the effectiveness of the developed facilities and complexes.

The purpose of the article is to select indicators for evaluating the informative (intelligence) availability of enemy radio sources for the acquisition of intelligence by means of electronic intelligence.

Assessment of the capabilities of the forces and means of the REI with respect to the informative (intelligence) availability of the sources of the REI is an element of the general methodology of the distribution of the forces and the means of intelligence and represents a set of statistical and logical methods of calculation, which are used in a certain logical sequence for the formation of adequate components - potential, technical and real IA sources of REI.

The selection of indicators for evaluating the informative (intelligence) availability of enemy radio sources for extraction of intelligence data by means of electronic intelligence conducted in the article makes it possible to:

evaluate the sources of REI in view of the feasibility of including in the plan of distribution of forces and means by tasks, objects and sources, for different conditions of the situation;

to rationally manage the forces and means of extraction and processing in the interest of solving the problems of the REI.

This approach can be applied at command posts of troop groups, military units, and REI units, and will allow the rational distribution of forces and assets across missions, objects, and sources.

Keywords: electronic intelligence, informative accessibility, intelligence objects, sources of radio emissions. 